\title{
Ectopic thyroid tissue in the lower neck with a coexisting normally located multinodular goiter and brief literature review
}

\author{
Eleni Kousta, Konstantinos Konstantinidis, Christina Michalakis, \\ George E. Theodoropoulos, Michalis Vorias, Michalis Georgiou, George Sambalis \\ Department of General and Laparoscopic Surgery, Athens Medical Center, Athens, Greece (K.K, G.E.T, M.V, M.G, G.S.)
}

\begin{abstract}
Ectopic thyroid tissue in the lower neck with a coexisting normally located multinodular goiter is a rare entity. We present a 27 -year old asymptomatic woman with a recent history of a painless mass in the left side of her lower neck. Thyroid function tests were normal. An ultrasound of her neck showed a multinodular goiter and a $3.4 \mathrm{~cm}$ solid mass in the left lower cervical area. These findings were confirmed by an MRI scan of her neck. The Tc99m Pertechnetate scan showed the presence of a functioning area under the left lobe of the thyroid gland. The patient underwent surgery. The cervical mass was identified as a structure separate from the left lobe of the thyroid, without any attachments to the body of the gland and was uniformly resected. A subtotal thyroidectomy was also performed. The histology revealed that the separate structure represented ectopic thyroid tissue. The patient had an uneventful postoperative recovery, subsequent to which she was euthyroid and had normal calcium levels.
\end{abstract}

Key words: Ectopic thyroid tissue, Multinodular goiter

\section{INTRODUCTION}

During embryogenesis the descent of the thyroid may not proceed normally, leading to various possibilities of anomalous locations of the gland. According to the timing of the embryonic insult, thyroid descent may stop at various sites, from the base of the tongue to an site of the thyroglossal duct ${ }^{1}$. Ectopic thyroid tissue, defined as thyroid tissue not

Address all correspondence to:

Dr Eleni Kousta, 6 S. Arvanitaki, Corfu 49100, Greece,

Tel: +30 26610 80561, Fax: +3026610 80562,

e-mail:1kousta@otenet.gr

Received 30-07-05, Revised 17-09-05, Accepted 10-10-05 located anterolaterally to the second and fourth tracheal cartages, is rare. In the majority of cases it is located in the midline, between the foramen caecum and the proper location of the thyroid gland, and most often it is found in the base of the tongue ${ }^{1,2}$. We present a rare case of ectopic thyroid in the lower cervical area in a patient with a multinodular goiter.

\section{CASE PRESENTATION}

A 27-year old woman presented with a recent onset of a painless mass in the left side of her lower neck. The patient was asymptomatic and there was 
nothing significant in her past medical history except for iron deficiency anemia. On examination she was found to have an approximately $3 \mathrm{~cm}$ soft, mobile, non-tender mass in her lower neck. Thyroid function tests were normal; TSH was $1.0 \mathrm{mU} / \mathrm{L}$ (normal range 0.3-4.5), FT4 $1.3 \mathrm{ng} / \mathrm{dl}(0.8-2)$, FT3 3.4 $\mathrm{pg} / \mathrm{ml}$ (1.8-5). Thyroid hormones and TSH were measured by electrochemiluminescence immunoassay (ECLIA). Calcitonin, calcium and PTH levels were normal. An ultrasound of her neck showed a multinodular goiter with 3 solid nodules on the left lobe of the thyroid, with a diameter of $1,0.7$ and 0.5 $\mathrm{cm}$, respectively. A $3.4 \mathrm{~cm}$ solid mass of heterogeneous echotexture was identified in the left lower cervical area below the left lobe of the thyroid, separate from the thyroid, behind the sternoclidomastoid muscle with peripheral and internal flow signals. The patient refused a fine needle aspiration. An MRI scan of her neck showed a $2.5 \times 2.2 \times 3.5 \mathrm{~cm}$ well defined mass below the left lobe of the thyroid on the border between the cervix and the thorax, extending retrosternally (Figure 1,2). The mass was suppressing the trachea but was not causing narrowing of the trachea. The mass appeared heterogeneous with hypervascularity. In the left lobe of the thyroid nodules 0.5-1 diameter were also noted.

The Tc99m Pertechnetate scan showed the presence of a functioning area under the left lobe of the thyroid gland with the rest of the thyroid gland appearing normal (Figure 3).

The patient underwent surgery in which the cervical mass was identified as a separate structure from the left lobe of the thyroid, without any attachments to the body of the gland, and was uniformly resected in a sharp fashion. The lesion appeared to represent a clearly ectopic thyroid tissue. A subtotal thyroidectomy was also performed.

Histology revealed ectopic thyroid tissue with an adenomatous nodule, fibrosis and calcifications. The left lobe of the thyroid had small colloid nodules.

The patient had an uneventful postoperative recovery. Postoperatively she was euthyroid and had normal calcium levels.
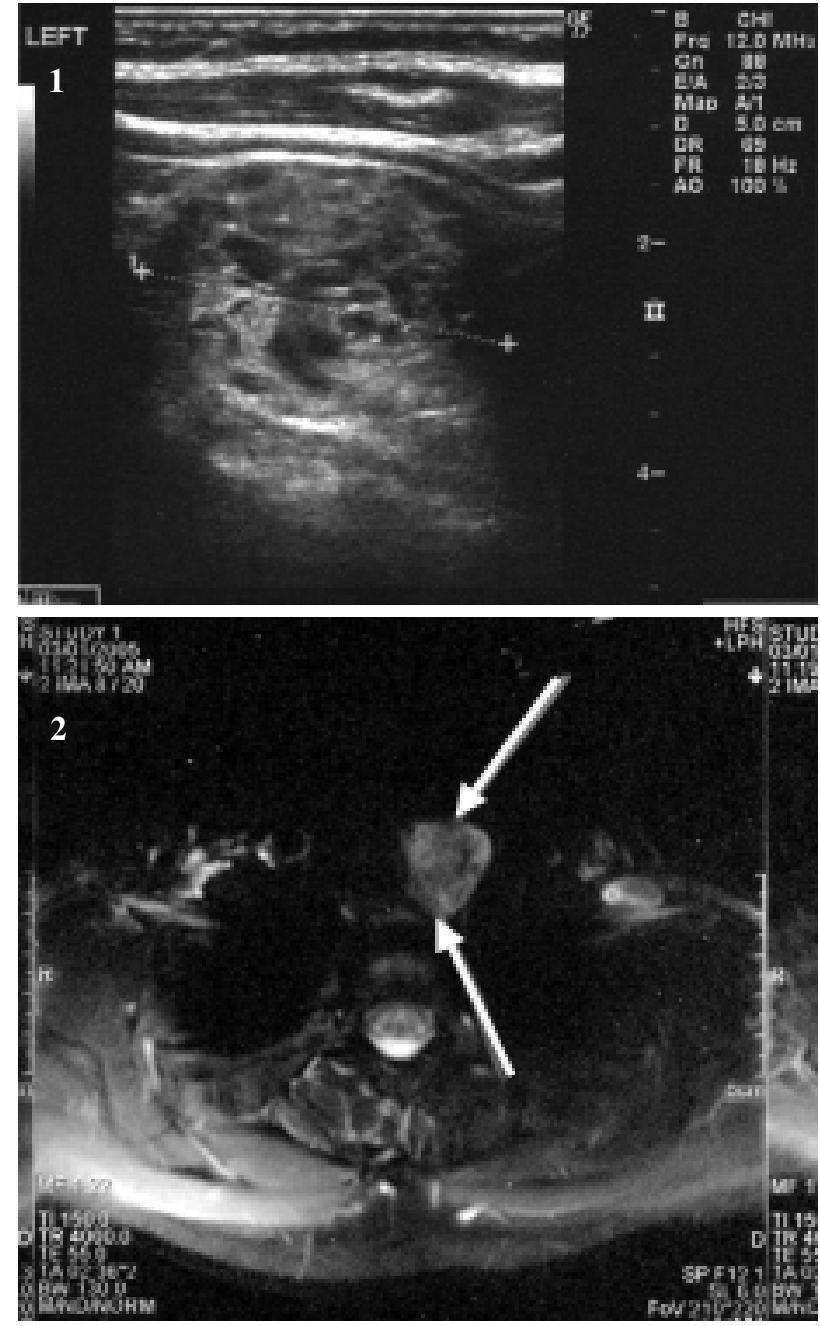

Figures $1 \& 2$. Transverse and longitudinal image of MRI scan of the neck showing a $2.5 \times 2.2 \times 3.5 \mathrm{~cm}$ heterogeneous mass below the left lobe of the thyroid on the border between the cervix and the thorax, extending retrosternally.

\section{DISCUSSION}

The thyroid develops from a median and two lateral primordial. The median anlage forms an endodermal diverticulum on the midline of the ventral pharynx, eventually forming the bulk of the gland. While lobulation occurs, it remains connected to the pharyngeal floor by the thyroglossal duct. The lateral anlagen arise as diverticula from the fourth and fifth pharyngeal pouches, eventually fusing with the median portion. Abnormalities in the development during embryogenesis may result in defective organogenesis and/or ectopic thyroid tissue. However, not all ectopic thyroid deposits can be explained by 


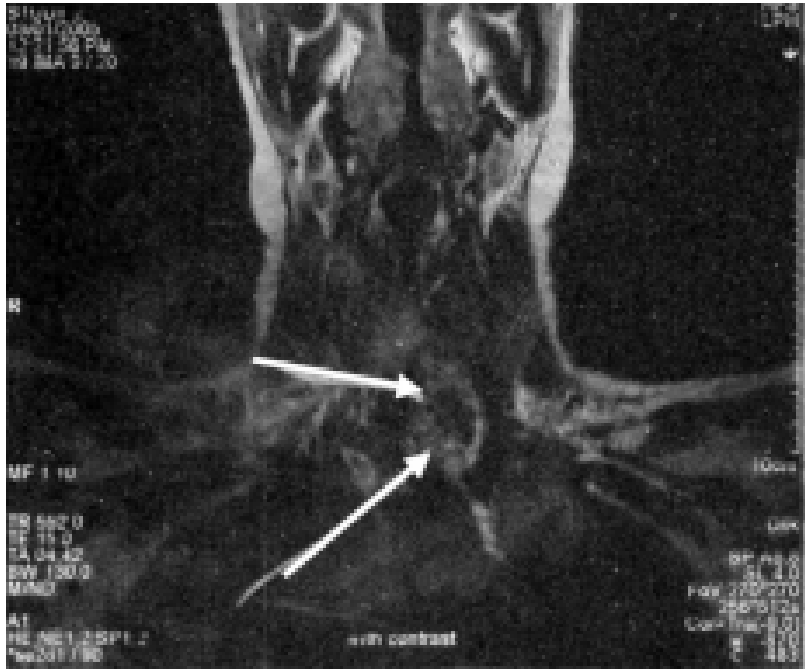

Figure 3. An image of the Tc99m Pertechnetate scan showing the presence of a functioning area under the left lobe of the thyroid gland with the remaining contour of thyroid gland appearing normal.

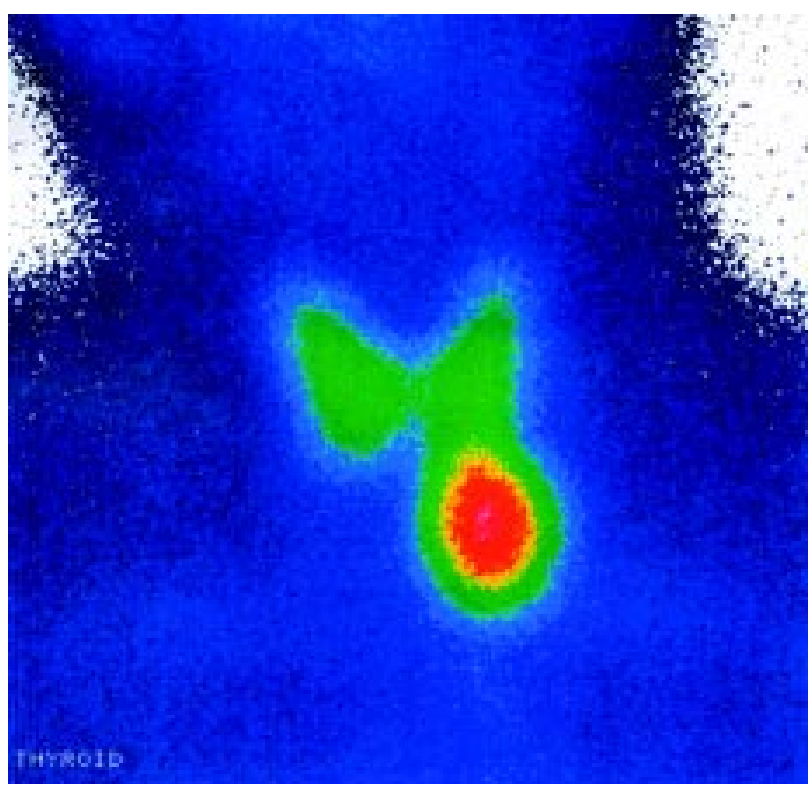

Figure 4.

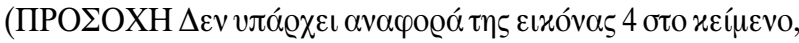

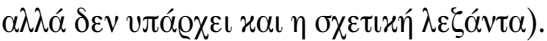

disturbances in embryonic development ${ }^{3}$.

Lingual thyroid is the most common form of thyroid ectopy ${ }^{3}$. Extralingual thyroid tissue is commonly located in the anterior cervical area, along the path of the thyroglossal duct ${ }^{1}$. In our patient it was locat- ed underneath the left lobe of the thyroid in the lower cervix, which is a rare location. Other rare locations of ectopic thyroid have been described in the submandibular region ${ }^{4,5}$, parotid salivary gland ${ }^{6}$, trachea $^{7}$, laterally to the carotid arteries and jugular veins $^{3}$, mediastinum ${ }^{8}$, heart ${ }^{9}$, lung ${ }^{10}$, duodenum ${ }^{11}$, adrenal gland ${ }^{12}$ and uterus ${ }^{13}$.

The incidence of thyroid ectopy is unknown. Postmortem studies suggest that asymptomatic thyroid tissue may be found along the path of the thyroglossal duct in as many as $7-10 \%$ of adults ${ }^{14}$. Ectopic thyroid tissue may coexist with a eutopic thyroid ${ }^{5,6,15}$, as in our patient, or may be the only functioning tissue $^{1,4,16}$. In a study of 230 patients with a clinical diagnosis of thyroglossal duct cyst, 4 cases of ectopic thyroid tissue presenting with eutopic thyroid and 3 cases without a eutopic thyroid were described, suggesting that the two may be equal in incidence ${ }^{17}$. However, in $70-75 \%$ of patients with lingual thyroid there was no eutopic thyroid tissue present in the pretracheal position ${ }^{18}$. Patients with a lingual thyroid and no eutopic thyroid commonly become hypothyroid at various times after birth because lingual ectopia is hypofunctioning ${ }^{3,19}$.

Ectopic thyroid tissue can undergo the same pathological changes as the eutopic thyroid gland, including thyrotoxicosis ${ }^{4}$, and can be benign or malignant ${ }^{7,8}$. Malignant transformation in ectopic thyroid tissue is rare. The estimated incidence for carcinoma arising in a lingual thyroid is only $1 \%{ }^{20-22}$. Among the 125 cases of intralaryngotracheal thyroid published prior to 1998, the estimated incidence of malignancy was similarly low $(1.6 \%)^{23}$. If, however, thyroid tissue is found in the lateral cervical lymph nodes, a metastasis of a malignant thyroid tumor should be excluded.

Thyroid dysgenesis, involving a spectrum of developmental abnormalities including ectopy, is associated with congenital hypothyroidism ${ }^{24,25}$. Genetic defects implicated in the etiology of thyroid dysgenesis include mutations in the paired box transcription factor (PAX8) and the thyroid transcription factors TTF1 and TTF2 25 . Heterozygous mutations in PAX8, a paired domain transcription factor involved in thyroid development and expression of the thyroid-peroxidase (TPO) and thyroglobulin (TG) 
genes, have been documented and characterized in sporadic and familial cases of thyroid hypoplasia or ectopy $^{26-28}$. The biochemical and morphological phenotype may vary among patients with the same PAX8 mutation ${ }^{26,28}$. The known molecular defects explain only a minority of the cases of thyroid dysgenesis, suggesting that there are defects in other transacting proteins remaining to be discovered ${ }^{25}$.

Ectopic thyroid tissue can pose difficult diagnostic and management problems. Ectopic thyroid tissue should be considered in the diagnosis of a cervical mass even in the presence of a eutopic thyroid gland. The diagnosis is usually ascertained by fine needle aspiration cytology. An ultrasound scan will determine whether a eutopic throid gland is present and technetium $99 \mathrm{~m}$ will identify functioning thyroid tissue. The treatment of choice for ectopic thyroid tissue is surgical removal or L thyroxin substitution therapy in children with lingual thyroid or thyroid tissue along the path of the thyroglossal duct.

\section{REFERENCES}

1. Larochelle D, Arcand P, Belzile M, Gagnon NB, 1979 Ectopic thyroid tissue - a review of the literature. $\mathrm{J}$ Otolaryngol 8:523-530.

2. Damiano A, Glickman AB, Rubin JS, Cohen AF, 1996 Ectopic thyroid tissue presenting as a midline neck mass. Int J Pediatr Otorhinolaryngol 34:141-148.

3. Batsakis JG, El-Naggar AK, Luna MA, 1996 Thyroid gland ectopias. Ann Otol Rhinol Laryngol 105:9961000 .

4. Kumar R, Gupta R, Bal CS, Khullar S, Malhotra A, 2000 Thyrotoxicosis in a patient with submandibular thyroid. Thyroid 10:363-365.

5. Mace AT, McLaughlin I, Gibson IW, Clark LJ, 2003 Benign ectopic submandibular thyroid with a normotopic multinodular goitre. J Laryngol Otol 117:739-740.

6. Mysorekar VV, Dandekar CP, Sreevathsa MR, 2004 Ectopic thyroid tissue in the parotid salivary gland. Singapore Med J 45:437-438.

7. Hari CK, Brown MJ, Thompson I, 1999 Tall cell variant of papillary carcinoma arising from ectopic thyroid tissue in the trachea. J Laryngol Otol 113:183-185.

8. Sand J, Pehkonen E, Mattila J, Seppanen S, Salmi J, 1996 Pulsating mass at the sternum: a primary carcinoma of ectopic mediastinal thyroid. J Thorac Cardiovasc Surg 112:833-835.

9. Casanova JB, Daly RC, Edwards BS, Tazelaar HD, Thompson GB, 2000 Intracardiac ectopic thyroid. Ann Thorac Surg 70:1694-1696.
10. Bando T, Genka K, Ishikawa K, Kuniyoshi M, Kuda T, 1993 Ectopic intrapulmonary thyroid. Chest 103:1278-1279.

11. Takahashi $\mathrm{T}$, Ishikura $\mathrm{H}$, Kato $\mathrm{H}$, Tanabe $\mathrm{T}$, Yoshiki T, 1991 Ectopic thyroid follicles in the submucosa of the duodenum. Virchows Arch A Pathol Anat Histopathol 418:547-550.

12. Shiraishi T, Imai H, Fukutome K, Watanabe M, Yatani R, 1999 Ectopic thyroid in the adrenal gland. Hum Pathol 30:105-108.

13. Yilmaz F, Uzunlar AK, Sogutcu N, 2005 Ectopic thyroid tissue in the uterus. Acta Obstet Gynecol Scand 84:201-202.

14. Sauk JJ Jr, 1970 Ectopic lingual thyroid. J Pathol 102:239-243.

15. Richards PS, Ahuja AT, King AD, 2004 Clinics in diagnostic imaging (101): Multinodular accessory thyroid tissue Singapore Med J 45:542-545

16. Aguirre A, de la Piedra M, Ruiz R, Portilla J, 1991 Ectopic thyroid tissue in the submandibular region. Oral Surg Oral Med Oral Pathol 71:73-76.

17. Radkowski D, Arnold J, Healy GB, et al, 1991 Thyroglossal duct remnants. Preoperative evaluation and management. Arch Otolaryngol Head Neck Surg 117:1378-1381.

18. Neinas FW, Gorman CA, Devine KD, Woolner LB, 1973 Lingual thyroid. Clinical characteristics of 15 cases. Ann Intern Med 79:205-210.

19. Noyek AM, Friedberg J, 1981 Thyroglossal duct and ectopic thyroid disorders. Otolaryngol Clin North Am 14:187-201.

20. Jarvis JF, 1969 Lingual thyroid: a report of three cases and discussion. Afr Med J 43:8-12.

21. Kamat MR, Kulkami JN, Desai PB, Jussawalla DJ, 1979 Lingual thyroid: a review of 12 cases. Br J Surg 66:537539.

22. Massine RE, Duming SJ, Koroscil TM, 2001 Lingual thyroid carcinoma: a case report and review of the literature Thyroid 11:1191-1196.

23. See AC, Patel SG, Montgomery PQ, Rhys Evans PH, Fisher C, 1998 Intralaryngotracheal thyroid-ectopic thyroid or invasive carcinoma? J Laryngol Otol 112:673-676.

24. Kreisner E, Neto EC, Gross JL, 2005 High prevalence of extrathyroid malformations in a cohort of Brazilian patients with permanent primary congenital hypothyroidism. Thyroid 15:165-169.

25. Kopp P, 2002 Perspective: genetic defects in the etiology of congenital hypothyroidism. Endocrinology 143:2019-2024.

26. Macchia PE, Lapi P, Krude H, et al, 1998 PAX8 mutations associated with congenital hypothyroidism caused by thyroid agenesis. Nat Genet 19:83-86.

27. Vilain C, Rydlewski C, Duprez L, et al, 2001 Autosomal dominant transmission of congenital thyroid hypoplasia due to loss-of-function mutation of PAX8. J 
Clin Endocrinol Metab 86:234-238.

28. Congdon T, Nguyen LQ, Nogueira CR, Habiby RL, Medeiros-Neto G, Kopp P, 2001 A novel mutation (Q40P) in PAX8 associated with congenital hypothy- roidism and thyroid hypoplasia: evidence for phenotypic variability in mother and child. J Clin Endocrinol Metab 86:3962-3967. 